\title{
Somaliland: The Journey of Resistance, Reconciliation and Peace
}

\author{
Iqbal Jhazbhay ${ }^{4}$ \\ Department of Religious Studies and Arabic, \\ University of South Africa
}

\section{ABSTRACT}

This article analyses the rise of the Somali National Movement (SNM), the trauma of resistance between northern, formerly British Somaliland, and the incumbent southern regime of General Mohammed Siad Barre, between 1984 and the collapse of that regime in 1991, and also revisits the Hargeisa, Somaliland, genocide of 1988. The year 1991 marked the move toward nation-statehood formation and the unilateral declaration of independence, interacting with the following interrelated socio-political dynamics: the reconciliation of Somaliland clans involving indigenous reconciliation initiatives of integrating tradition and modernity; interactions between the majority Isaaq clan and the minority clans; followed by the 1991-93 politics of transition; post-conflict stabilisation involving national reconciliation conferences and elections.

"Hadduu oday jiro, uu u ood rogo, abaaroodkana way orgootaa". If there is an elder who looks after the herd, then animals will produce offspring even in the dry season (Somali proverb). ${ }^{5}$

\section{Introduction}

The on-going Somaliland reconciliation process that culminated in the declaration of Somaliland's independence on 18 May 1991 represents a unique

Please direct all correspondence to: iqbal@unisa.ac.za

A tribute to the wisdom of elders. 
blend of modernity and tradition born of the suffering of the people of the northwest Somali coast (see map below). The map in Figure 1 is presented here to give a sense of the geographical dimensions of the contestations regarding Somaliland and in no way implies a clear-cut and settled border. The map depicts the colonial border between British Somaliland and Italian Somaliland in Northern Somalia. Legally, this border was dissolved in July 1960. It has been reintroduced as a state border by Somaliland but is seriously contested and not internationally accepted.

\section{Figure 1}

Map of the Horn of Africa. (Source: The Economist, 382, 8512, p. 46.)

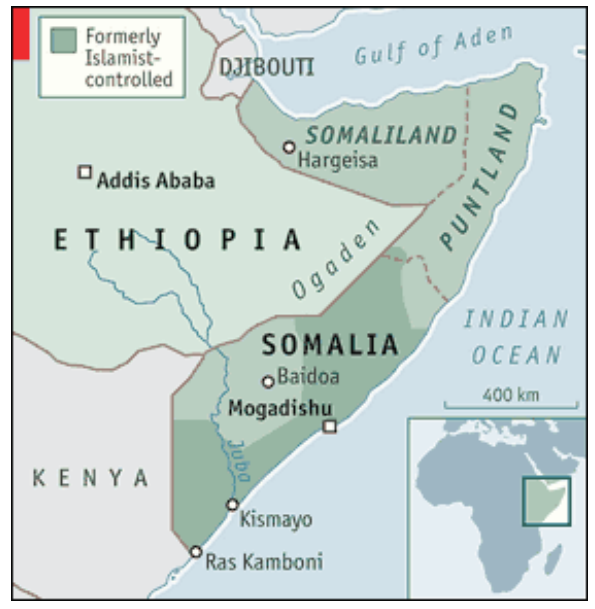

Under the ancien regime, General Mohammed Siad Barre waged a war of repression against this region - a trauma that effectively undermined his Greater Somalia project, as did the failed Ogaden campaign of 1978 which Barre launched to capture the Ogaden Somali region in Ethiopia. The dynamics of reconciliation in Somaliland revolve around the complex interplay between the forces of modernity, represented by the Somali National Movement (SNM - a post-colonial liberation-cum-resistance movement aimed at ridding Somaliland of Barre's military garrisons) and the indigenous forces of tradition vested in the north-west region's clan leadership (Adam, 2003; Drysdale, 2000).

This interplay between tradition and modernity represented a departure from what, until then, had essentially been a top-down, negotiated transfer of political power from the British and Italian colonial elites to nationalist elites. 
However, after independence, the absence of nationalist social transformation came back to haunt even the mono-ethnic cultural region of the Somali coast. ${ }^{6}$ In Somalia, it manifested itself as a post-colonial breakdown in governance, with civil war and chronic unrest threatening the state's cohesion and eventually leading to its failure and collapse.

This article reviews the rise of the SNM, the trauma of repression and resistance between northern, formerly British Somaliland, and Barre's incumbent regime between 1984 and the collapse of that regime in 1991, and also revisits the Hargeisa, Somaliland, genocide of 1988. The year 1991 marked the initial move toward nation-statehood formation and the unilateral declaration of independence interacting with the following interrelated sociopolitical dynamics: the reconciliation of Somaliland clans involving indigenous reconciliation initiatives; interactions between the majority Isaaq clan and the politically less powerful: Iise, Gadabursi, Dhulbahante and Warsengeli, followed by the 1991-93 politics of transition involving reconciliation conferences within Somaliland and influences of the international community.

\section{"Xeer Soomaali"7 Under British Colonialism: Elders as the Midwives of Somaliland's Reconstruction}

It is necessary to compare the British and Italian colonial legacies along the Somali coast in order to gain a perspective on the foundations of post-conflict reconciliation that have thus far benefited Somaliland. In his observations, Drysdale (2000, 2004), a British insider in the politics of the region, sheds light on why, from the vantage point of history, Somalia is experiencing such problems in reconstituting itself in the south.

He points out that the former British Somaliland Protectorate had three concurrent legal systems:

\footnotetext{
6 This has also been the case in much of the rest of Africa. The continent is plagued by nominal nation states with, by and large, weak national identities. Somalis continue to have a strong national Somali identity, known as "cultural nationalism", yet the project of political reform and democratisation remains weak. In the case of Somaliland, democratisation has emerged, but is very fragile.

7 Xeer pronounced as heer refers to customary Somali law, such as unwritten contracts, laws, agreements or social codes among clans.
} 
- Secular law, in the English language;

- Islamic law, in the Arabic language; and

- Unwritten Somali traditional law.

Under the British administration, unwritten Somali law "was exercised exclusively by Somali elders . . . knowledgeable in traditional law [who] operated in both town and country in the six districts . . administered by British District Commissioners" (Drysdale, 2004, p. 4). The elders were helped in the execution of their court orders by informal "clan police" established by the British district commissioners (Drysdale, 2004). Although their traditional law is ancient and largely unknown to the outside world, Somalis remain comfortable with its rulings in all aspects of life. ${ }^{8}$

In terms of traditional law, every Somali is guaranteed collective support from and protection by his or her "tol", "a self-contained group of genealogical lineage" run by chosen elders (Drysdale, 2004, p. 5). The thousands of tols in Somalia are independent of the government of the day and receive no remuneration for their services. However, "governments which have no love of tols frequently use or misuse their energy and talents in the interest of good or bad governance" (Drysdale, 2004, p. 6).

The public re-emergence of tols in 1991, after two decades of underground activity, had been fostered three years earlier by the SNM. Experiencing problems with recruitment, the SNM called on Somaliland elders to persuade their tol followers to join the movement. The SNN commanders, impressed by the elders' success in recruiting new members, brought them in as advisers and afforded them equal status. In 1991, when the SNM gained victory over Barre's garrisons and formed a government, "the elders were given a place of honour and [resumed] their open-handed work with almost ordained honesty . .." (Drysdale, 2004, p. 5).

Thus, it can be seen that in the case of Somaliland, the political liberation movement and the traditional authorities had not been pre-ordained to join

8 Traditional law addresses issues, such as "revenge killings" (Somali: argoosi), and punishments, including capital punishment, according to Islamic norms, personal liberty, collective compensation, peacemaking, consensus decision-making and how to avoid autocratic political power, and includes case histories. Xeer is partly mixed with Sharia norms and diverges in some respects from Islamic law. It is complex and there are scant texts on the subject. It discourages incarceration or capital punishment, since a family may not be deprived of desperately needed labour. 
forces against the tyranny of the Barre regime. Their cooperation came about as a result of the armed struggle imposed on the north-west region and the need for the exiled SNM to root itself firmly in the region in order to mount a successful military resistance. In this way, the region's clan elders became the midwives of Somaliland's rebirth, consciously or unconsciously.

To arrive at an understanding of present-day Somaliland, we must revisit its first taste of independence between 1960 and 1969 when British Somaliland experienced a brief period of republican union with former Italian Somaliland. This was followed by the Barre dictatorship, repression and near "genocide" as perceived by its leaders, which eventually rekindled the region's nationalist impulses.

\section{The Somali National Movement: North-West Resistance Takes Shape}

The SNM came into being partly in response to the repression of Barre's dictatorship (Africa Watch Report, 1990) (Scholars are probing exactly what are some of the reasons for the SNM's establishment). As a regionally based, post-colonial resistance movement, it represented the north-western clan of the Isaaqs, centred on the three major urban centres of Hargeisa, the second largest city along the Somali coast, Burco and Berbera, a strategic port city. Non-Isaaq clans and sub-clans represented in the SNM included the Dir clan groups from the south in former Italian Somaliland, individual members of the Gadabursi clan groups, and the Warsangeli and Dhulbahante clans. According to Davies, the SNM was founded "more or less simultaneously by different groups of individuals in Saudi Arabia, Mogadishu and London" (1994, p. 12). Davies describes the London group, who met on 6 April 1981, as "secular and nationalist in its political outlook", whereas the Saudi-based group was "religious and quite ardent in [its] support of the Isaac [Isaaq]" (1994, p. 13). The religious group seems to have been more influential during the SNM's formative years, but its influence started to wane in 1983 when the SNM's base moved from London to eastern Ethiopia and its 10-year-long guerrilla war against Barre's forces intensified (Bradbury, 2008; Davies, 1994; Lewis, 1994). However, both the SNM and the second presidentof the Republic of Somaliland, Mohamed Haji Ibrahim Egal, had to contend with strong internal religious sentiments (Egal was initially against secession but later remain committed to this ideal until his death). A case in point was the inscription of the Islamic 
religious formula on the flag of the Republic of Somaliland. The challenge of arriving at a balance between religion and modernity in Somaliland persists to this day (Goth, 2005).

The SNM had been born of a sentiment of marginalisation. Southern dominance in the Republic of Somalia triggered sporadic Isaaq unrest throughout the post-independence period. Yet, despite the periodic unrest, marginalisation and savage military repression that ensued in the late 1980s, the SNM's longterm driving force remained a "unified desire to oppose the oppressive socialist dictatorship of General Barre, rather than to support any particular clans . . . Therefore, it collected intellectuals with a wide variety of political views who shared this common goal [namely an inter-clan expression of pan-Somali nationalism]" (Davies, 1994, p. 13 ). According to Davies, the SNM also wanted "to decentralize much of the power of [the central government in Mogadishu]" (1994, p.13), but short-term motivation of stopping the "genocide" of the Isaaq clan by General Barre focused its goals on a narrower, clan basis.

It was in the wake of the 1978 Ogaden defeat that endemic inter-clan and sub-clan instability gained momentum in Somalia. The emergence of an Isaaqled resistance with a regional inter-clan and clan character unfolded within the wider context of Somali unrest and resistance against the increasingly defensive Mogadishu dictatorship.

The SNM resistance was part of a broader insurgency to unseat the Barre regime. The SNM's military campaign, launched in 1988, resulted in the capture of Burco on 27 May, and the capture of a substantial part of Hargeisa on 31 May 1988. The savagery of government retaliation forced some 300000 Somalilanders to flee to Ethiopia, which further fuelled the insurgency. Some 5000 Isaaqs were killed between May and December 1988. Broadly, the SNM's history can be categorised in three phases: 1981-88, 1988-91 and 1991-93, when the SNM came into power. Broadly, the first phase is the formative phase, the second when it operated without Ethiopian patronage and the third when the SNM formally came into power in Hargeisa.

The SNM must be viewed within the framework of a broader Somali resistance to better understand its uniqueness when compared to other Somali movements, and how this uniqueness relates to the reconciliatory nation-building process that has been underway in Somaliland over the past several years. 


\section{The Proliferation of Somalia's Liberation Movements}

In terms of an historical and contemporary perspective on the politics of conflict and accommodation along the Somali coast, Davies (1994) offers a typology of Somali liberation movements that may be instructive in contextualising the SNM insurgency and its legacy. He differentiates between "genuine" liberation movements and "new" liberation movements - the latter mainly reflecting the fission and fusion of political formations during the post-Barre period. ${ }^{9}$

Besides the SNM, Davies (1994) classifies the following as being or having been "genuine" Somali liberation movements:

- The Somali Salvation Democratic Front (SSDF) which at times has been the Somali Salvation Front (SSF);

- The Somali Patriotic Movement (SPM) and the two factions that it split into: SPM Ogadeni and SPM Harti;

- The United Somali Congress (USC) and the two factions that it split into: USC "Aidid" and USC Mahdi; and

- The Somali Democratic Movement (SDM) and the two factions that it split into: SDM pro "Aidid" and SDM pro Mahdi.

The SNM's democratic uniqueness lay in the fact that, apart from having a preponderant clan-base in the Isaaqs, it did not try to expand by including members from even more clans and clan groups, although it had an ideological thrust that attracted individuals from other clans. Davies remarks: "In sharp contrast to other liberation movements at that time, the SNM did make a serious effort to use internal democratic procedures to develop political goals based upon an internal consensus - and to publish them" (1994, p.13). Davies also cites a typical statement of the SNM published in 1981:

9 Davies (1994) provides insightful commentary on the international politics of Somali liberation and "reconciliation": "Any two Somalis can get together and form a new "liberation movement" that claims to represent any group of people they want to claim. International "reconciliation conferences" that give one vote to each faction admitted, use almost nonexistent "liberation movements" in order to deliberately distort voting rights at these conferences. This practice began at the two Djibouti Conferences in the Summer of 1991. More recently, the US State Department and the United Nations in particular have been using this technique to inflate the importance of minor liberation groups that support their own stated goals, in order to weaken the influence of genuine liberation movements that oppose some of their views, particularly concerning recognition of the Republic of Somaliland. Therefore, Somalis are beginning to argue that only "genuine" liberation movements who fought against the dictatorship prior to January 1991 should be admitted as real factions to such "reconciliation conferences" [italics added]. 
We propose a new political system built on Somali cultural values of cooperation rather than coercion; a system which elevates the Somali concept of "Xeer" or inter-family social contract in which no man exercised political power over another except according to established law and custom, to the national level (1994, p. 14) [italics added].

Instructive, in this regard, is the following, taken from the 11 guidelines published by the SNM and quoted by Davies:

- The structure of the central and regional government will be as simple as possible. They will be designed to reduce hierarchy and bureaucracy to a minimum and enable the average man and woman to understand and relate to regional and national governments;

- It will integrate effectively traditional Somali egalitarianism and the requirement of good central government;

- It will maximise the effectiveness of the representative and democratic process at all levels; and

- The freedom of the press in accordance with the constitution and the laws of the country will be guaranteed by law (1994, p. 14).

\section{The Somali National Movement's Comparative Advantage in an Escalating Struggle}

Building on a cohesive clan base, combined with an essentially pan-Somali democratic ethos, the SNM's strategy, according to Davies (1994), was to assist other clan and regional groups to embark on their own resistance against the Barre dictatorship. The SNM succeeded in attracting non-Isaaqs, though Barre also did well in trying to undermine this attraction. Other foreign countries appear to have cooperated with Barre in developing the theory that since the SSDF had stopped its armed resistance, the SNM was the only foe left. If the SNM could be induced to abandon its armed struggle, he would face no further conflict and opposition. Despite the various bribes offered, the SNM refused to end its war of liberation.

Barre's attempted divide-and-conquer ploy formed a crucial backdrop to the escalation of the SNM's insurgency in the north during 1988 and the regime's savage retaliation. This escalation was directly linked to mutual sell-outs of liberation proxies by Colonel Mengistu of Ethiopia and Barre in the interest of the survival of their respective regimes. 
In April 1988, Mengistu struck a peace deal with Barre in terms of which they agreed to stop supporting liberation movements based in their respective countries that were launching raids into the other country. In this way, they hoped to force the SNM to withdraw from the border, and move deeper into Ethiopia, which would make it impossible for the movement to launch raids into Somalia. The opposite ensued: the SNM moved its militias into Somalia (Davies, 1994). Opposition to Barre's regime intensified and Somalia's civil war escalated to the point of the collapse of the regime in 1991.

The fact that the SNM was able to make the transition from external, crossborder raids to fully fledged internal insurgency indicates that its "modern" nationalist leadership succeeded in accommodating the traditional authority of the region's clan elders in the spirit of Xeer Soomaali. Nevertheless, the SNM had its own internal contradictions which, according to Farah and Lewis (1997), came back to haunt Somaliland after independence. During the armed struggle the SNM managed to suppress long-held civilian-military leadership rivalries, but these erupted after the overthrow of Barre and during the early phase of state formation. During the struggle, the SNM's military leadership wanted to transform it into a professional, efficient military and political body but did not succeed because of the movement's clan character. Yet, the SNM's dependence on Isaaq clansmen made it responsive to the wishes of the wider population, particularly traditional leaders (Reno, 2003). Like most of the public, traditional leaders in turn supported the civilian leaders in the power struggle within the SNM and continued to do so in the post-military period (Farah \& Lewis, 1997). This tilt toward civilian ascendancy, based on the SNM's popular base, was key to its survival during the nadir of the Barre regime's savage reprisals.

Thus, the ascendance of a civilian elite was critical to the SNM's survivalist self-reliance and self-sufficiency during the armed struggle. However, this proved to be at the cost of deferring the resolution of civil-military leadership tensions within the movement. When these leadership tensions resurfaced violently in 1991 during the early phase of Somaliland's state formation, they would act to further entrench the traditional leadership of clan elders as the society's leading agents in conflict prevention, management and resolution. In a very real sense, the clan elders have served to guarantee peace and security in Somaliland in that they are the nation's ultimate fall-back as an "insurance policy" against descent into anarchy. The clan elders also became the SNM's main fall-back during the state-building phase of democratic post-conflict 
stabilisation. Most clan elders played a positive role towards Somaliland's stabilisation. Some were overly politicised and corruptible (Hoehne, 2007).

\section{Enter the Clan Elders: Post-Conflict Stabilisation}

From the late 1980s until the collapse of the Barre regime, the SNM apparently did most of the fighting in the resistance war receiving substantial assistance from the USC and the SPM only in the last one to one-and-a-half years of the war. The neighbouring SSDF also played an important role in Somali resistance politics, including directing radio Kulmis jointly with the SNM. Once the armed struggle had come to an end, the initiative in Somaliland shifted to the clan elders as the SNM entrusted them to navigate what would become a complicated and delicate process of post-conflict reconciliation and political consolidation of a brutalised society that had been under prolonged siege. The backdrop to the unfolding of this national reconciliation phase led by clan elders in the north-west was the collapse of the state in Mogadishu, which followed on the heels of the collapse of the Barre regime. It was the USC, a powerful force in Mogadishu, that seized control of the capital only to have the situation deteriorate into factional fragmentation and in-fighting that ushered in what became an era of reign of the warlords in former Italian Somalia.

The shift of the initiative from the SNM (the politico-military vanguard of the struggle against Barre) to the more popular-based leadership of the clan elders was underlined by the manner in which Somaliland moved from insurgency toward the outright declaration of independence. After Barre's defeat in January 1991 and the February peace conference in Berbera that proclaimed a formal ceasefire, the SNM called a meeting of the elders of all non-Isaaq clans in March "to reconcile any potential differences between them and the Isaaq clans - as agreed upon by all liberation movements before the end of the war-of-liberation" (Davies, 1994, p. 15). Some elders opposed the declaration of independence, but the SNM leadership was forced to act by mass-demonstrations of SNM rank and file and some returnees from refugee camps in Ethiopia.

The Berbera peace conference established the SNM's policy of peaceful coexistence among the clans of Somaliland. This was a tense conference with many non-Isaaq elders who were afraid of being killed by the SNM. The post-Berbera, non-Isaaq meeting was followed by a meeting in April with 
the Isaaq clan elders in Hargeisa, setting the stage for the SNM congress of representatives of all clans at the end of April. The congress became known as the Guurti Congress of the Elders. The elders and other selected elected representatives forced the SNM to announce the creation of the independent Republic of Somaliland on 18 May 1991. The declaration was accompanied by the establishment of an SNM-led interim government. Its administration was based on the SNM's organisational structure, with its chairman, Abdulrahman Ali Tuur appointed as the country's first executive president. The SNM's central committee functioned as the government's first parliament.

With the emphasis on reconciliation, the interim government was tasked with accommodating non-Isaaq communities by enlisting their participation in the new regime. It also had to embark on constitutional development and prepare Somaliland for an elected government. However, the interim government was acutely vulnerable to the devastation left by the war, and also to long-deferred civil-military leadership tensions in the SNM.

Bereft of a revenue base with which to rebuild an administration, a decimated infrastructure, and with a large number of people displaced from the south or in refugee camps, the government had little capacity to deal with the growing number of freelance militia who were making a living through robbery and extortion (Bradbury, Abokor, \& Yusuf, 2003, p. 459).

In addition, there was a particularly critical political deficit, which needed attention.

While the Burco conference had restored relations between the Isaaq and other northern clans, "it failed to heal the schisms within the SNM and among the Isaaq that had developed during the war" (Bradbury, 1997, p. 17). Old wartime rivalries within the SNM resulted in the outbreak of fighting in Burco. In March 1992, fighting also erupted in Berbera when the interim government sought to establish control over the port and its revenue. The Berbera confrontation threatened to push Somaliland into a state of protracted civil war that would have replicated the southern deconstruction of former Italian Somaliland. Fortunately the clan elders restored peace, thereby entrenching their stabilising role. 


\section{The Sheikh and Borama Conferences: Towards a Traditional-Modern Pact}

Somaliland's elders stepped in to re-establish peace by convening two major clan conferences in the towns of Sheikh and Borama. According to Bradbury et al. (2003), the Sheikh conference was significant in that it resolved the conflict over Berbera Port and confirmed its status as a public asset, which ensured that future Somaliland governments would have a source of revenue with which to build an administration. It also established a framework for participation of the elders of all clans in Somaliland's post-war government, namely, the national guurti (council of elders). The council would be responsible for controlling clan militia, preventing acts of aggression against other communities, and protecting Somaliland (Farah \& Lewis, 1997). This framework for internal security (which was consolidated at the subsequent Borama conference) was important for what Brons describes as a "society-rooted process towards state formation" (2001, p. 250).

Finally, the intra-Isaaq nature of the Berbera conflict had required the mediation of non-Isaaq elders, in this instance, the Gadabuursi guurti. Their participation in the Sheikh conference indicated that the SNM's influence was declining and that if it was to be sustained, Somaliland needed the buy-in of non-Isaaqs.

The defining event in Somaliland's post-conflict politics was the shir beeleed (community conference) held in Borama from January to May 1993, where:

An electoral college of elders who made up the national guurti, oversaw the peaceful transfer of power from the SNM government of Abdulrahman Tuur to a civilian government headed by Egal, who had been Somalia's last civilian prime minister before the 1969 military coup (Bradbury et al., 2003, p. 450).

The Borama conference produced an interim Peace Charter and a transitional National Charter. The Peace Charter re-established the basis for law and order by setting out a code of conduct (or Xeer, written and unwritten contracts, laws, agreements or social codes among clans) for the people of Somaliland in accordance with their traditions and the principles of Islam. The National 
Charter defined the political and institutional structures of government for a transitional three-year-period, until a constitution could be adopted (Bradbury et al., 2003).

Bradbury et al. contend that the Borama conference was important in the postwar context for the way in which it addressed issues of representation and power-sharing, namely "by institutionalising clans and their leadership into the system of governance. The National Charter established what has become referred to as a beel (clan or community) system of government" (2003, p. 460). Described as a "dynamic hybrid of Western form and traditional substance" (SCPD, 1999, p. 22), the government consisted of an executive (Golaha Xukuumadda) with a president, vice-president and a council of ministers, a legislature, comprising a bicameral parliament with an upper house of elders (Golaha Guurtida) and a house of representatives (Golaha Wakiillada), and an independent judiciary. Although the shir beeleed was intended to be in place for only three years, it lasted for a decade.

The beel system of government recognised kinship as the organising principle of Somali society. In essence, the government became a power-sharing coalition of Somaliland's main clans, integrating tradition and modernity in a holistic governance framework - a framework for fostering popular participation in governance or participatory governance, which might best define the essence of democracy without the encumbrance of a Western connotation. Presidential appointments to the executive were made to ensure a clan balance. In the upper and lower houses of parliament, seats were proportionally allocated to clans. However, the patrilineal clan system meant that women were excluded from representative politics, because it was not clear whether a woman would represent her husband's clan or that of her father.

\section{Reconciliation, a Divergent Perspective: Somaliland and Puntland}

The magnitude of Somaliland's achievements in constructing what Farah has referred to as a "culture of locally based reconciliation processes" (1999, p. 4) may be better appreciated from his critical assessment of strengths and weaknesses of Somaliland and Puntland as divergent examples of "two relatively stable de facto political entities in northern Somalia" (1999, p. 4), responding to the larger post-Barre upheavals along the Somali coast. This comparison is not 
just academic, given the fact that neighbouring Somaliland and Puntland have long been at logger-heads over the future political reorganisation of the Somali coast; a predicament that has been taken to another level now that Puntland's former leader, Abdullahi Yusuf Ahmed, has become the Ethiopianbacked interim president of the latest attempt at reconstituting southern Somalia - the Transitional Federal Government (TFG) - which emerged from the Inter-Governmental Authority for Development (IGAD) sponsored Nairobi reconciliation peace talks. Comparing and contrasting Puntland's and Somaliland's reconciliation strategies may also be instructive for revealing how both, taken together, point toward some major shifts that may be underway in contemporary African thinking about governance and the reconstitution of the African state in the new age of the African Union (AU).

Within the contested terrain of how the Somali coast region of the Horn of Africa is to be reconstituted, Somaliland, Puntland (Cabdiraxmaan, 2005) and southern Somalia may be approached conceptually as a continuum of alternative futures:

- The reconstitution of Somalia as a centralised state along the lines of the first post-independence republic;

- The reconstitution of Somalia as a federal state comprising autonomous regions as reflected in the Puntland initiative; and

- The reconstitution of Somalia as a region comprising independent sovereign states as reflected in the emergence of an independent Somaliland Republic.

The centralised state option that would, in effect, take the region back to the status quo ante, prior to the overthrow of the Barre dictatorship, has been rejected. Yet, there remains no consensus between the federalist and sovereign independence options. Indeed they are in confrontation, as reflected in the outbreak of border hostilities that occurred soon after Ahmed's selection as the TFG's new interim leader - SNM-SSDF rivalry by other means? As such, the confrontation between Somaliland and Puntland/TFG challenges the sustainability of Somaliland in two respects in terms of the following questions:

1 Is Somaliland's "culture of locally based reconciliation processes" sustainable within a regional environment where it is in confrontation with the rest of the Somali region? 
2 To what extent are Somaliland's gains in national reconciliation increasingly contingent on a broader reconciliatory process gaining hold within the Somali region as a whole?

It is against this backdrop that the strengths and weaknesses of Somaliland's national reconciliation can be assessed in gaining an understanding of its achievements, in comparison with its Puntland neighbour. Farah (1999) distinguishes Somaliland and Puntland in the following terms:

Culturally, Woqooyi Bari Soomaalia (north-east Somalia) is clearly defined by clan exclusiveness and the traditional territorial control of the large Majerteen clan and allied Darood groups (Leylkase, Awrtable and others). In this sense, north-east Somalia differs from Somaliland, as it constitutes a more socially cohesive political entity. Somaliland, on the other hand, supports a population of mixed (and rival) clan origin belonging to three large clan families (Dir, Isaq and Harti/Darood). This makes Somaliland socially and politically more complex than northeast Somalia ... While Somaliland's experience in peacekeeping and governance had been relatively violent (yet constructive), north-east Somalia has witnessed domestic stability at the cost of political stagnation ... traditional leaders in both Somaliland and north-east Somalia emerged as paramount political actors in the post-military period. In Somaliland, the guurti have been politicized since 1993 when they were institutionalised as one of the two chambers of parliament in the new administration formed in Borama. The Interim Charter of Puntland, however, failed to legislate a similar status for the Isimo who themselves have played a similar role in north-east Somalia, securing internal stability and driving the grassroots political process that culminated in the Garowe conference (1999, p. 4).

In Farah's (1999) estimation, Somaliland has presented a much higher risk proposition than Puntland, though the Somaliland experiment has progressed much further. Given the reasons he cites, this may be instructive for the future of both Somaliland's nation-building future and the TFG's prospects. Both Puntland and Somaliland, relative to the rest of the Somali region, have benefited from the reconciliatory role of the clan elders. In Puntland's case, however, as Farah (1999) points out, prolonged competition for the 
chairmanship of the SSDF by "two prominent Majerteen political leaders, Col. Abdillahi Yusuuf (ex-military officer and now former president of Puntland State) and his arch-rival Gen. Mohamed Abshir Musa (ex-police commissioner and vigorously opposed to Yusuuf) paralysed the SSDF since 1994" (1999, p. 3). This essentially military - as opposed to civilian - leadership rivalry prevented the SSDF leadership and the Isimo - "titled clan and sub-clan heads and lineage leaders" (Farah, 1999, p. 2) - from achieving any progress in the area of political rebuilding. Indeed, according to Farah, "the process of building basic institutions of governance remained frozen in a kind of permanent and uncertain transition prior to the declaration of statehood by Puntland in July 1998" (1999, p. 2).

Undoubtedly, in the case of Somaliland and the SNM, the relatively more clearly defined and coherent articulation of a political programme by a civilian nationalist elite, with a more organic connectivity to its social base, benefited the political rebuilding process, which has since steadily advanced. Hence, Farah ventures: "The relatively more constructive experience of Somaliland in governance in the post-military period and its multi-ethnic composition makes it an interesting case to watch in the process of rebuilding wider political structures from a patchwork of clan-fiefdoms" (1999, p. 5). Yet, according to Farah, to Puntland's credit, "unlike in the SNM, competition for control of the organization and local administration did not degenerate into" (1999, p. 5) what he describes as "the devastating internal power struggle witnessed in Somaliland in the transitional period" (1999, p. 5). Here, unlike in many renditions of the Somaliland experience, Farah delves at some depth into unpacking its contradictions, rooted in the SNM's history:

Old divisions within the military and civilian wings of the SNM resurfaced more intensely in the post-military period, in the absence of a common foe. Opposition to Tuur's administration coalesced around the alan cas faction of the SNM, which accused the government of having a civilian bias and deliberately underrepresenting the military wing. Dominated by the military elite of the SNM (who were either dissatisfied with their status in Tuur's administration or were aspiring for high office in the new administration), the opposition also included civilian politicians with a vested interest in ending Tuur's administration (1999, p. 17). 
Against this backdrop, Tuur's attempt to expand the interim government's authority outside Hargeisa - as successive Modagishu regimes had failed to do in the south - by establishing a national army from the clan-based SNM militia only exacerbated matters by helping to trigger inter-clan warfare. In March 1993, the interim government organised a multi-clan force in order to establish control over the vital Berbera Port, which brought Somaliland to the brink of civil war. This prospect motivated the clan intervention, which set off the series of successful reconciliation conferences that have managed to stabilise Somaliland ever since (Bradbury et al., 2003, p. 459).

Writing in 1999, Farah hopes that a "peaceful and constitutional transition" (p. 5) would spare Puntland a similar internal conflict. Unfortunately this hope did not come to the fore. Veering from the path of constitutionalism, Abdullahi Yusuf, instead pursued the route of strongman, warlord rule over Puntland while vying for ultimate leadership of a successor to the failed Transitional National Government (TNG) in Somalia, and, at the same time, stoking border tensions with Somaliland. In following this route, Puntland's experience has exposed the limits of clan power in deterring warlord political ambitions. In 2001, the region's clan elders elected Jama Ali Jama as the new head of Puntland. This was immediately rejected by Colonel Yusuf, who alleged the vote was "futile and illegal", thus triggering a war against Jama's forces, which ended in May 2002 with the defeat of the latter's forces at Qardo (Barise, 2002).

Somalilanders, meanwhile, saw Yusuf's strongman rule in Puntland as merely a stepping stone for his real objective of ultimately heading up a successor to the failed TNG in Mogadishu which, with Ethiopia's support - Ethiopia, also widely seen as pro-Somaliland - he ultimately achieved. In commenting on Yusuf's stewardship in Puntland and his candidacy for heading up the new TFG, Roble said that:

He has shown to the IGAD states and Somalis alike that no other person other than him would govern Puntland. With the exception of Mohamed Abdi Hashi, Vice president of Puntland who regularly disagreed with and publicly challenged him, Abdullahi Yusuf has often gotten his way and treated Puntland as his fiefdom. For example, he has been taking almost $\$ 250,000$ monthly for the last 22 months from the region for his campaign use in Nairobi. This was done over the objection of the vice president and the House of Representatives who would have 
liked to give more priority to the worsening drought conditions in the Sool, Sanaag and Buuhoodle regions (2004).

\section{Somaliland's Contested Consolidation: From Reconciliation to Constitutionalism}

After the Berbera conflict, the clan reconciliation process in Somaliland moved towards constitutionalism, but still with the ultimate aim of consolidating the independence of the north-west Somali coast. The change from the SNM interim administration of Tuur to that of Egal was effected peacefully within the framework of the Borama process.

Egal is, in effect, the founding father of the Somaliland Republic. However, his tenure would undergo a baptism by fire that would test, yet again, the sustainability of reconciliation in Somaliland. Over the first 18 months of his administration, the republic's foundations were secured, institutions of government were established, the militia was demobilised, a revenue system was created, and a secure environment for economic recovery was provided. The initial pressing problems of the day made any movement on constitutional matters virtually impossible and since contested issues from the Borama conference still had to be addressed. Only in 1997, were constitutional matters given attention (Renders, 2006).

According to Bradbury et al., as Egal's government "sought to extend its administrative control, dissatisfaction grew among certain Isaaq clans with the formula for sharing political power adopted at the Borama conference. This, combined with political opportunism by certain politicians, pushed Somaliland into civil war" (2003, p. 461). The fragility of both the reconciliation process and Somaliland's independence was underlined when a section of the opposition to Egal's administration, the Gerxajiis, the close relatives of the previous President, Tuur, declared their support for a federal Somalia. The war lasted from November 1994 to October 1996, displacing over 180000 people and causing severe damage to Burco and Hargeisa - areas that were still trying to recover from the devastation left by the war against Barre. A third national reconciliation conference (Shir Qarameed), held in Hargeisa between October 1996 and February 1997, ended the civil war, thereby accelerating Somaliland's constitutional development. Egal's political leadership survived the war due to the fact that an electoral college of elders extended his tenure 
by another four years. This group of elders also increased the opposition and minority seats in the house of parliament, while an interim constitution was adopted that superseded the Borama charters and provided the basis for a multi-party system of government.

The Hargeisa conference was financed and managed with little foreign support. The conference was attended by double the number of voting delegates that attended the Borama conference, including a number of women who were permitted to attend as observers. The fact that there was no change in governmental leadership meant that the civil war had failed to disrupt the country's governance, thereby providing for continuity in Somaliland's transition. Egal co-opted elders via patronage politics. Since the conference, Somaliland has experienced a period of uninterrupted security, which has facilitated its continuing constitutional, political and socio-economic development.

\section{Post-Conflict Constitutional Development}

In the aftermath of the civil war, the interim constitution adopted at the Hargeisa conference enshrined principles to enhance the development of stable civil-military relations. The constitution clearly defines the "institutional functions and mandates of security and civilian institutions, while at the same time adopting democratic rules governing access by the elite to high public office regardless of professional bias" (Farah, 1999, p. 25).

In addition to institutionalising the regulation of civil-military relations within a constitutional framework, the interim constitution set out a schedule for the legalisation of political parties and the holding of democratic elections. It would take four years, however, before a referendum would be held on the new constitution. According to Bradbury et al., "Egal linked the transition to multi-party democracy with Somaliland's desire to gain international recognition, arguing that the international community would not recognise Somaliland's independent status unless it adopted such a system" (2003, p. 463). They continue by pointing out that "a major impetus for implementing the constitution was the formation of Puntland in 1998 and the TNG in 2000", stressing that "Puntland, which claims authority in areas of eastern Somaliland, and the TNG, which claims sovereignty throughout Somalia, directly challenged the legitimacy of Somaliland". Somaliland's constitutional consolidation, therefore, was intimately linked to its regional security interests 
within the broader, fluid context of the reconstitution of the state along the Somali coast. Puntland was viewed as the "enemy", attempting to undermine Somaliland's hard-earned peace. This push factor played an important role in cohering Somaliland's clans.

With article 1 of the constitution affirming Somaliland's independent status, the constitutional referendum of 31 May 2001 effectively was a vote on the status of Somaliland vis-à-vis the rest of the Somali region (Bradbury et al., 2003). This constitutional confirmation of Somaliland's status set the stage for the institutionalisation of the country's multi-party political system, in a phase that would extend the constitutionalisation of reconciliatory nation-building towards a consolidation of democracy. The Somaliland parliament legalised the formation of political organisations on 6 August 2001, and scheduled presidential elections for February 2002. Egal followed up this legalisation of political organisations by announcing the formation of Somaliland's first such organisation - the Democratic United Peoples' Movement (UDUB). With a further six organisations registering by the end of September 2001, the politics of Somaliland began making the transition beyond the SNM's liberation movement era and its turbulent aftermath towards a more normalised phase of civilian democratic governance. As this transition unfolded, the power sharing system of governance established during the Borama conference proved critical to the process of reconciliation and recovery in Somaliland, succeeding where numerous efforts in Mogadishu have, to date, failed.

\section{Somaliland's Electoral Transition}

The new constitutional system introduced the principle of universal suffrage thereby extending to women the right to vote. Within the context of the electoral system the installation of the different tiers of government has been a bottom-up process, starting with local district elections. These involved electing 379 councillors to 23 district and municipal councils in Somaliland's six regions. According to Bradbury et al., "the reason for starting with a district election was to determine which three parties would contest the presidential and parliamentary elections" (2003, p. 265). Besides UDUB, Egal's political organisation, "the local elections were contested by six organisations: ASAD, HORMOOD, Kulmiye, SAHAN, UCID, who were able to demonstrate adequate support in six regions" (Bradbury et al, p. 465). 
In December 2001, a National Electoral Commission was established to oversee elections. A number of problems became apparent:

- Electoral commissioners lacked experience in managing elections;

- The political organisations had neither experience in contesting elections nor the resources for running one;

- No consideration was given to selecting women candidates;

- There had been no voter education;

- Somaliland's media lacked experience in covering elections;

- There was a mutual lack of trust among political organisations, and between them and the electoral commission;

- The participation of the Sool and eastern Sanaag regions was controversial (and, undoubtedly, their being contested terrain within Puntland) ${ }^{10}$ and

- The lack of census statistics and an electoral register.

Civil society organisations played an important role in addressing some of these problems. Their involvement helped generate an environment of popular participation that, with outside technical assistance and expertise, as well as funding for training from for example the European Commission and the USbased International Republican Institute (IRI), helped to carry Somaliland through an important learning curve.

By the time voting in local elections were underway in 2002, Egal had passed away in South Africa, and had been succeeded by former Vice-President Daahir Rayale Kaahin of the Gadabuursi clan. Voting in the district elections occurred on 15 December 2002, at 726 out of 800 polling stations. Because of security considerations, they did not take place in Sool, eastern Sanaag and parts of the Buudhoodle district in Togdheer region. A total of 440067 valid votes were counted and 332 district councillors were elected. Kaahin's party, UDUB, was the clear winner, followed by a cluster of close competition between UCID (30 676 votes), Kulmiye (29 923 votes) and HORMOOD (29 104 votes). Because of the problems experienced with the district elections, making additional electoral legislation necessary, the presidential and parliamentary election time-tables were delayed. The presidential election took place in April 2003.

A separate paper is required to analyse the situation in the Harti inhabited regions of Sool and Sanaag in Somaliland. The Harti opposition to Somaliland's secession, however, is a very important aspect of Somaliland's political situation today, as the repeated clashes in Sool since December 2002 between Somaliland and Puntland forces show. The Puntland forces, usually, have been supported by the local population against Somaliland troops that cannot administer their own border in the east. This of course has an impact on Somaliland's de facto statehood. 
Efforts were made by the Somaliland National Electoral Commission (NEC) to ensure that democratic practices were followed by all parties. Yet, the NEC had few powers to control the parties' campaigns. Kulmiye outspent the governing UDUB party of the president, raising money from the Somaliland business community and the diaspora. Kaahin, however, was elected in a poll that generally received favourable reviews from international and domestic observers, though various irregularities were noted. As a result, the closeness of the contest "presented a harsh test for Somaliland's aspiring democracy" (Bradbury et al., 2003, p. 469) as UDUB outpolled Kulmiye by a mere 80 votes. What is more, according to Bradbury et al. (2003), UDUB supporters as well as the supporters of Kulmiye had expected the latter to emerge victorious. The outcome triggered small protests in Burco and Gabiley, which are Kulmiye strongholds. However, in spite of fears that there might be outbreaks of violence, such destabilisation failed to materialise. This was the result of the government's emergency precautions and the Kulmiye leadership's decision not to contest the outcome, though it did present evidence of mathematical miscalculations by the NEC.

In the end, in accordance with electoral law, the Supreme Court delivered the final verdict in favour of the ruling UDUB, increasing its victory margin to 214 votes after submissions by all parties and the NEC. The outcome was immediately contested by Kulmiye, in the process, raising questions about the court's competence as well as highlighting Somaliland's weak judicial system. This is a point of increasing concern among Somalilanders ${ }^{11}$ who, in fact, question the Supreme Court's independence from the executive. Bradbury et al. draw a number of conclusions from the April 2003 presidential elections and their district election antecedents:

- The extent of UDUB dominance is important because "the elections . . . drew attention to the issues of the decentralisation of government and political power" which, given the disastrous experience of centralised authoritarian rule from Mogadishu, influenced the 1993 Borama Charters and the subsequent constitution in the direction of institutionalising a decentralised system of government "as a way of preventing a return to authoritarian rule and strengthening popular participation in government" (2003, p. 471), thus: 
. . . the election of district and municipal councils that are accountable to the local electorate holds great potential for creating a form of government that is responsive to local needs and one that will prevent the recentralisation of political power (2003, p. 474).

This last implication drawn from the district and presidential electoral experience has a broader regional significance within the larger Somali coast context. Decentralisation within Somaliland and the existence of an autonomous Puntland, linked to the federalist outcome of the Nairobi talks, resulting in the current TFG, indicate an overall direction in post-Barre Somali political culture toward a decentralised reconstitution of the state within the greater Somali region. Whatever the outcome of the contestation between Somaliland and the rest of the Somali region, a future centralisation of power along the Somali coast is highly unlikely. This fact will dictate the terms of a future reconciliatory dynamic within the region if such a process emerges. For details of the reconciliation process, see Goth (2005). Here, to bring the problems and prospects of Somaliland's reconciliation experience up to date, it may be useful to speculate on these broader reconciliation prospects vis-à-vis Somaliland and the rest of the Somali region.

\section{Reconciliation: A Lutta Continua}

The effective ascendancy of decentralised state-building in Somaliland and the greater Somali region has grown organically from the political, territorial and military fragmentation that has been so much a feature of the destabilisation of the region, in the wake of the collapse of the Barre regime. The fracturing of Somali society has emerged dialectically in over-reaction to the hypercentralisation of power during the Barre period coupled with, in Somaliland's case, the marginalisation and ultimate alienation of an entire region and its peoples. Reversing fragmentation appears to have led naturally to a decentralising "equilibrium", which has given impetus to another ascendant trend: the re-assertion of the very "clanism" depicted derisively by some "modernisers" but which, in fact, has played a pivotal stabilising role, as expressed in the interventions of clan elders as the arbiters of conflict and accommodation. ${ }^{12}$

12 It also has to be noted that clanism in the sense as identified by Samatar (1993), as a destructive force, contributed to the fragmentation of Somalia. Later, elders were able to counter-balance these destructive forces. 
In the case of Somaliland, clan leadership ascendancy was facilitated by the SNM's modernising nationalism which, ideologically, sought to bridge the cultural gap between tradition and modernity and which, from the standpoint of self-reliant pragmatic survival, depended on the clan elders as pillars of support in mobilising the social base for insurgency and postconflict governance. Because of external isolation, Somalilanders have had, as Bradbury et al. put it, "certain freedom to craft an indigenous model of modern African government that fuses indigenous forms of social and political organisation within a democratic framework" (2003, 475). Herein may reside one path toward transcending the African post-colonial predicament of "the bifurcated state", as described by Mamdani (1996, pp. 16-18). Indeed, local and historical particularities will have to be considered.

Organised differently in rural areas from urban areas, the governing inheritance bequeathed by colonialism was a state that, according to Mamdani, "was Janusfaced, bifurcated. It contained a duality: two forms of power under a single hegemonic authority", which counter-poised the modernising "civil power" of rights and freedom to the "customary power" of custom and tradition, each signifying "one face of the same bifurcated state" (1996, pp. 16-18).

Clan leadership, as the arbiter of national reconciliation in Somaliland, appears to have assisted the north-western brand of Somali nationalism in overcoming this bifurcating legacy. This same social stratum of leadership consequently emerged as a key actor in the ongoing efforts to revive a semblance of government in former Italian Somalia, where "clanism" was once anathema. Only there, unlike in Somaliland (or at least to the same degree), interclan dynamics were to become complicated by the militarised balkanisation of a factionising southern Somalia, a process that gave rise to that region's "warlord" phenomenon, and the parasitic political economy and culture it has spawned. While the logic of decentralisation ultimately prevailed over external pressures for a "unified" - read, unitary centralised - Somalia, the jury remains out on whether or not the TFG can replicate the reconciliatory dynamic that has characterised the north-west in the south, much less reconcile with the reality of an independent Somaliland. Somaliland itself is still undergoing its own process of consolidating reconciliation into sustainable statehood. Developments in southern Somalia between 2006 and 2008 have further complicated the situation with the gruesome war of Ethiopian and TFG forces against Islamic groups. Many young Somalis have been radicalised and have joined Islamic extremist groups. 
Provided that the IGAD states, the AU and key state actors, such as South Africa and neighbouring Ethiopia, are able to prevent hostilities between Somaliland and Somalia, the latter's five-year transitional phase that its TFG must navigate, could provide ample space for Hargeisa and Mogadishu to work on their respective nation-building/re-building projects and, perhaps, converge toward a workable accommodation. Throughout the Mbagathi talks, which gave rise to the TFG, Somaliland was vigilant on the question of those talks not presuming to incorporate its region into the scope of the settlement being sought. However, as recently as Kaahin's trip to South Africa in late January 2005, his Foreign Minister, Edna Adan Ismail, made it clear that Hargeisa sought good relations with Mogadishu (Ismail, 2005).

In the process, Ismail downplayed border tensions between Somaliland and Puntland, while indicating that whatever happened in the Republic of Somalia, it had to address the interests of Somaliland.

\section{Somaliland, Reconciliation and the New Logic of Continental Union}

In short, Somaliland is by no means a "finished product" within the larger context of reconciliation along the Somali coast. Should a convergence in the politics of reconciliation in Somaliland and southern Somalia progress toward an eventual co-equal political arrangement between the two, the logic of such an evolution would dovetail with the larger logic of federation-building in greater East Africa and the continent as a whole (Bryden, 2004). Bearing in mind that the year 2010 is not far off, and the fact that 2010 is also the year in which Somalia's federal transition would culminate in a reconstituted republic, there should be ample room for the AU and key members of its PSC, such as Ghana, South Africa and Ethiopia, to work with Somaliland and Somalia in nurturing a reconciliation process that: informs new approaches to the question of diplomatic recognition; expands their and the AU's options within the larger unfolding geopolitical context of a greater East Africa; and possibly revisits the aspirations of pan-Somali reconciliation within a broader pan-African framework, as opposed to the old OAU nation-state constraints. By implication, these constraints meant that pan-Somali nationalism could be nothing more than the destabilising irridentist force that it, in fact, turned out to be. Somaliland's reconciliation process, which has been an "example" (US State Department, 2005) for the rest of the Somali coast could, if reconciliation 
takes hold in the south, return the region to a pan-Somali future, intimately intertwined with the larger unfolding pan-African future of greater East Africa.

\section{REFERENCES}

Adam, H. (2003). Somalia: International versus local attempts at peacebuilding. In R. Mathews (Ed.), Durable peace: Challenges for peacebuilding in Africa. Toronto: University of Toronto Press.

Africa Watch Report. (1990). A government at war with its own people. Somalia, testimonies about the killing and the conflict in the north. London: Africa Watch.

Baldacci, G. (1909). The promontory of Cape Guardafui. Journal of the Royal African Society, 9, $59-72$.

Barise, H. (2002, May 7). Somali warlords battle for Puntland. Retrieved June, 15, 2006, from http://news.bbc.co.uk/1/hi/world/africa/1972557.stm

Bradbury, M. (1997). Somaliland country report. London: CIIR.

Bradbury, M. (2008). Becoming Somaliland. Oxford: James Currey.

Bradbury, M., Abokor, A.Y., \& Yusuf, H.A. (2003). Somaliland: Choosing politics over violence. Review of African Political Economy, 30(97).

Brons, M.H. (2001). Society, security, sovereignty and the state in Somalia: From statelessness to statelessness?. Utrecht: International Books.

Bryden, M. (2004). Somalia and Somaliland: Envisioning a dialogue on the question of Somali unity. African Security Review, 13(2), 23-33.

Burton, R. F. (1987 [1856]). First footsteps in East Africa: Or an exploration of Harrar (Vols. I \& II). New York: Dover.

Cabdiraxmaan, J. (2005). Consolidation and decentralization of government institutions. In Wartorn Societies Project International (Ed.), Rebuilding Somaliland. Issues and possibilities (pp. 49-121). Lawrenceville, NJ: Red Sea Press.

Cruttenden, C.J. (1849). Memoir on the Western or Edoor tribes, inhabiting the Somali Coast of N.-E. Africa, with the southern branches of the family of

Darrood, resident on the banks of the Webbe Shebeyli, commonly called the River Webbe. Journal of the Royal Geographical Society of London, 19, 49-76.

Davies, J.L. (1994, August 27). The liberation movements of Somalia. Retrieved June 22, 2008, from http://www.civicwebs.com/cwvlib/africa/somalia/1994/lib_movments/lib_movements.html

Drysdale, J. (2000). Stoics without pillows: A way forward for the Somalilanders. London: HAAN.

Drysdale, J. (2004). A study of the Somali hybrid insurance system and the consequences of its rejection by Southern Somalia's political leadership. Unpublished paper.

Farah, A.Y. (1999, April). Political actors in Somalia's emerging de facto entities: Civil military relations in Somaliland and Northeast Somalia, Project Ploughshares. Paper presented at the Conference on Civil-Military Relations, Nairobi. Retrieved April 4, 2008, from http://www. somaliawatch.org/archivefeb01/010414202.html

Farah, A.Y., \& Lewis, I.M. (1997). Peace making endeavour of contemporary lineage leaders in Somaliland. In H. M. Adam \& R. Ford (Eds.), Mending rips in the sky: Options for Somali communities in the 21st century. Lawrenceville, NJ: Red Sea Press. 
Goth, B. (2005, December 9). Taking the new opposition dominated parliament to task. Retrieved June 22, 2008, from http://www.awdalnews.com/wmview.php?ArtID=6603

Hoehne, M.V. (2007). From pastoral to state politics: Traditional authorities in Northern Somalia. In L. Buur \& H.M. Kyed (Eds.), A new dawn for traditional authorities? State recognition and democratisation in sub-Saharan Africa (pp. 155-182). New York: Palgrave.

Ismail, E. A. (2005, February 3). Somaliland - Africa's most secret success story. Unpublished lecture delivered at the South African Institute of International Affairs. Retrieved June 22, 2008, from http://www.awdalnews.com/wmprint.php?ArtID $=4760$

Lewis, I.M. (1961). A pastoral democracy: A study of pastoralism and politics among the northern Somali of the Horn of Africa. Oxford: Oxford University Press.

Lewis, I.M. (1994). Blood and bone: The call of kinship in Somali society. Lawrenceville, NJ: Red Sea Press.

Luling, V. (2002). Somali sultanate. The Geledi City-State over 150 years. London: HAAN.

Mamdani, M. (1996). Citizen and subject: Contemporary Africa and the legacy of late Colonialism. Oxford: Oxford University Press.

Renders, M. (2006). Traditional leaders and institutions in the building of the Muslim Republic of Somaliland. Unpublished PhD thesis, University of Ghent.

Reno, W. (2003). Somalia and survival in the shadow of the global economy, Queen Elizabeth House: Working Paper (No. 100). Oxford: University of Oxford.

Roble, F. (2004, September 17). "Is Colonel Abdullahi Yusuf the next president?". Retrieved July, 19, 2005, from http://www.somalilandnet.com/somaliland_voice/articles/12859.shtml

Samatar, A.I. (1989). The state and rural transformation in Northern Somalia, 1884-1986. Madison: University of Wisconsin Press.

Somaliland Centre for Peace and Development (SCPD). (1999). A self-portrait of Somaliland: Rebuilding from the ruins. Hargeisa: .

US State Department. (2005, October 3). Regional parliamentary elections in Somalia. Retrieved June 22, 2008, from http://www.state.gov/r/pa/prs/ps/2005/54215.html 